\title{
BMJ Open Clinicobiochemical prediction of biopsy-proven cases of severe hepatic fibrosis in patients with chronic hepatitis $C$ infection
}

\author{
Young-Joo Jin, ${ }^{1}$ Ju Hyun Shim, ${ }^{2}$ Gi Ae Kim, ${ }^{2}$ Eunsil Yu, ${ }^{3}$ Kang Mo Kim, ${ }^{2}$ \\ Young-Suk Lim, ${ }^{2}$ Han Chu Lee ${ }^{2}$
}

To cite: Jin Y-J, Shim JH, Kim GA, et al.

Clinicobiochemical prediction of biopsy-proven cases of severe hepatic fibrosis in patients with chronic hepatitis $\mathrm{C}$ infection. BMJ Open 2014;4:e006255. doi:10.1136/bmjopen-2014006255

- Prepublication history for this paper is available online. To view these files please visit the journal online (http://dx.doi.org/10.1136/ bmjopen-2014-006255)

Received 31 July 2014 Revised 21 October 2014 Accepted 3 November 2014

CrossMark

\begin{abstract}
${ }^{1}$ Department of Internal Medicine, Inha University Hospital, Inha University School of Medicine, Incheon, Republic of Korea

${ }^{2}$ Department of

Gastroenterology, University of Ulsan College of Medicine, Asan Liver Center, Asan Medical Center, Seoul, Republic of Korea

${ }^{3}$ Department of Pathology, University of Ulsan College of Medicine, Asan Liver Center, Asan Medical Center, Seoul, Republic of Korea
\end{abstract}

Correspondence to Professor Ju Hyun Shim; s5854@medmail.co.kr

\section{ABSTRACT}

Objective: To evaluate clinicobiochemical factors predicting severe hepatic fibrosis in patients with chronic hepatitis $\mathrm{C}$ virus (HCV) infection.

Setting: Tertiary institution.

Participants: 859 treatment-naïve Korean patients with HCV who underwent liver biopsy. Severe fibrosis was defined as fibrosis stage $\geq 3$ based on the METAVIR system.

Primary outcome measures: Clinicobiochemical factors predicting severe hepatic fibrosis.

Results: The median serum alanine aminotransferase (ALT) level was $68 \mathrm{IU} / \mathrm{L}$ and body mass index (BMI) was $24.2 \mathrm{~kg} / \mathrm{m}^{2}$. Severe fibrosis was observed in 326 $(39.7 \%)$ of the 859 patients. The frequencies of severe fibrosis were $0 \%, 37.8 \%, 41.9 \%$ and $42 \%$ in patients with serum ALT concentrations (IU/L) of $\leq 20,20-30$, $30-40$ and $>40(p<0.01)$, respectively, and $10.7 \%$, $19.8 \%, 30.5 \%, 39.2 \%$ and $55.6 \%$ in patients $<30$, $30-40,40-50,50-60$ and $\geq 60$ years old, respectively $(p<0.01)$. Categorised age in years $(50-60$ (OR 4.26, $\mathrm{p}=0.03)$ and $\geq 60(\mathrm{OR} 7.53, \mathrm{p}<0.01)$ compared with $<30$ ), categorised ALT level in IU/L (20-30 (OR 16.76, $\mathrm{p}<0.01$ ), 30-40 (OR 20.02, $\mathrm{p}<0.01$ ) and $>40$ (OR 21.49, $p<0.01)$ compared with $\leq 20)$ and $B M l>27.5 \mathrm{~kg} / \mathrm{m}^{2}(\mathrm{OR}$ $1.65, p=0.03$ ) were independently related to severe fibrosis in patients with chronic HCV. The severe fibrosis rate was $60.6 \%$ in patients aged $\geq 50$ years with ALT $>20 \mathrm{IU} / \mathrm{L}$ and $\mathrm{BMI}>27.5 \mathrm{~kg} / \mathrm{m}^{2}$.

Conclusions: More advanced age ( $\geq 50$ years), obesity and serum ALT>20 IU/L are associated with severe fibrosis in patients with chronic HCV. Anti-HCV therapy may be considered for these patients without histological confirmation, regardless of HCV genotype. A wait-and-see policy may be justified for patients with serum ALT $\leq 20 \mathrm{IU} / \mathrm{L}$.

\section{INTRODUCTION}

Hepatitis C virus (HCV) infection is a leading cause of chronic liver disease. ${ }^{12}$ An estimated $70-85 \%$ of patients with HCV infection develop chronic hepatitis ${ }^{3}$ and approximately $30 \%$ of these patients progress to liver cirrhosis over two or three decades following the

\section{Strengths and limitations of this study}

- Severe hepatic fibrosis was present in almost $40 \%$ of the patients with chronic hepatitis C virus with serum alanine aminotransferase (ALT) level greater than $20 \mathrm{IU} / \mathrm{L}$.

- However, severe hepatic fibrosis was not observed in any patient with a serum ALT level of $20 \mathrm{IU} / \mathrm{L}$ or less.

- Furthermore, older age ( $\geq 50$ years), obesity and elevated levels of serum ALT (>20 IU/L) were closely associated with severe hepatic fibrosis in these patients.

- In particular, severe hepatic fibrosis was observed in about $60 \%$ of patients aged $\geq 50$ years with serum ALT concentrations $>20 \mathrm{IU} / \mathrm{L}$ and body mass index (BMI) $>27.5 \mathrm{~kg} / \mathrm{m}^{2}$.

- Thus, our findings suggest that the presence of these high-risk factors for severe hepatic fibrosis may justify an active antiviral approach without liver biopsy findings.

- Major limitation of the current study is that the data are from a single institution and a single ethnic type.

- Because of the differences in procedures for serum ALT measurement in different clinical laboratories and the fact that Asian BMI cut-off points differ from those of Western populations, further multicentre and multiethnic studies are required for external validation and wider use of our estimates.

infection. ${ }^{4}$ It is known that the stage of fibrosis observed in the initial liver biopsy can predict the likelihood of progression to cirrhosis in patients with chronic $\mathrm{HCV}^{5}$ Furthermore, American Association for the Study of Liver Disease (AASLD) guidelines advise antiviral treatment for patients with severe fibrosis confirmed by liver biopsy, if serum HCV RNA results are positive. ${ }^{6}$ Thus, it is important to differentiate severe hepatic fibrosis from nonsevere fibrosis in order to determine whether antiviral treatment should be initiated. 
To assess the extent of hepatic fibrosis in patients with chronic HCV infection, liver biopsy has been the standard test, despite the possible complications. ${ }^{78}$ However, the issue of whether patients with chronic HCV should undergo routine liver biopsy to determine the extent of fibrosis remains controversial. ${ }^{9}$ Furthermore, liver biopsy may be unnecessary for patients with genotype 2 or 3 chronic HCV because these individuals achieve a high sustained virological response (SVR) rate of more than $80 \%$ to standard therapy. ${ }^{6}{ }^{10-12}$ However, there is an ongoing debate about whether routine liver biopsy is warranted for patients with genotype 1 chronic HCV, whose antiviral response rate is still about $66-75 \%$ after triple therapy with pegylated interferon, ribavirin and protease inhibitor, which is a standard of care recently set by global guidelines. ${ }^{13-17}$

A previous study in a European population suggested that about $65 \%$ of patients with chronic HCV with normal alanine aminotransferase (ALT) levels have a degree of hepatic fibrosis of at least F1 based on the METAVIR scoring system. ${ }^{18}$ However, it is not clear whether the extent of hepatic fibrosis, especially severe fibrosis, in Asian patients with chronic HCV can be based on data from Western populations. Furthermore, to date, there are only limited data on definite clinical or biochemical factors that can predict the development of severe hepatic fibrosis in Asian patients with chronic HCV infection, although the efficacy of proposed non-invasive fibrosis indexes has been validated in such patients. ${ }^{19}$

The aim of the current study, therefore, was to assess the extent of severe hepatic fibrosis in Korean patients with chronic HCV. We also aimed to identify prehistological clinical and biochemical factors predictive of severe hepatic fibrosis.

\section{PATIENTS AND METHODS}

\section{Study subjects}

Between January 1995 and December 2010, 937 consecutive patients were diagnosed as having chronic HCV infection at Asan Medical Center and underwent liver biopsy for evaluation of liver histology before antiviral treatment was initiated. All the patients were positive for anti-HCV antibody and HCV RNA, but none had any history of antiviral treatment for HCV. The diagnosis of chronic HCV infection was based on the AASLD criteria. $^{6}$

Of a total of 937 patients, 78 were excluded because they were under 16 years old $(n=10)$, were co-infected with hepatitis $B$ virus $(n=9)$, had a history of renal $(n=3)$ or liver transplantation $(n=43)$, or malignancy (lymphoma $(n=1)$, cholangiocarcinoma $(n=4)$, lung cancer $(n=1)$ and melanoma $(n=1))$, or consumed more than $40 \mathrm{~g}$ of alcohol per week $(\mathrm{n}=6)$. Finally, 859 patients were enrolled in the present study, which was approved by the Institutional Review Board of Asan Medical Center (protocol number: 2012-0404).

\begin{tabular}{|c|c|}
\hline Variables & HCV $(n=859)$ \\
\hline Age (years), $\mathrm{n}(\%)^{*}$ & $52(19-77)$ \\
\hline$<30$ & $28(3.3)$ \\
\hline$\geq 30$ and $<40$ & $111(12.9)$ \\
\hline$\geq 40$ and $<50$ & $223(26.0)$ \\
\hline$\geq 50$ and $<60$ & $263(30.6)$ \\
\hline$>60$ & $234(27.2)$ \\
\hline Gender (male), n (\%) & $487(56.7)$ \\
\hline $\mathrm{BMI}\left(\mathrm{kg} / \mathrm{m}^{2}\right), \mathrm{n}(\%)^{*}$ & $24.2(13.9-38.5)$ \\
\hline$<23$ & $303(35.3)$ \\
\hline$\geq 23$ and $<27.5$ & $424(49.4)$ \\
\hline$\geq 27.5$ & $132(15.4)$ \\
\hline \multicolumn{2}{|l|}{ Genotype, n (\%) } \\
\hline 1 & $396(46.1)$ \\
\hline 2 or 3 & $441(51.3)$ \\
\hline Others & $22(2.6)$ \\
\hline AST (IU/L), n (\%)* & 59 (10-939) \\
\hline$\leq 20$ & $43(5.5)$ \\
\hline$>20$ and $\leq 30$ & $112(21.5)$ \\
\hline$>30$ and $\leq 40$ & $112(13.0)$ \\
\hline$>40$ & $592(68.9)$ \\
\hline ALT (IU/L), n (\%)* & $68(9-961)$ \\
\hline$\leq 20$ & $73(8.5)$ \\
\hline$>20$ and $\leq 30$ & $90(10.5)$ \\
\hline$>30$ and $\leq 40$ & $86(10.0)$ \\
\hline$>40$ & $610(71.0)$ \\
\hline Platelet count $\left(\times 10^{3} / \mathrm{mm}^{3}\right)^{*}$ & $165(56-385)$ \\
\hline $\mathrm{APRI}^{*}$ & $0.92(0.1-43.2)$ \\
\hline FIB-4* & $2.1(0.2-53.1)$ \\
\hline Cholesterol (mg/dL)* & $154(38-274)$ \\
\hline $\mathrm{DM}, \mathrm{n}(\%)$ & $12(1.4)$ \\
\hline \multicolumn{2}{|c|}{$\begin{array}{l}\text { *Median (range). } \\
\text { ALT, alanine aminotransferase; APRI, aspartate } \\
\text { aminotransferase-to-platelet ratio index; AST, aspartate } \\
\text { aminotransferase; BMI, body mass index; DM, diabetes mellitus; } \\
\text { FIB-4, fibrosis-4; HCV, hepatitis C virus. }\end{array}$} \\
\hline
\end{tabular}

\section{Laboratory data}

The activities of serum biomarkers such as aspartate aminotransferase (AST), ALT and glucose were measured at the time of initial liver biopsy before antiviral treatment was initiated. Data were also obtained before liver biopsy on age, gender, body weight $(\mathrm{kg})$, height $(\mathrm{m})$, body mass index (BMI), hepatitis B surface antigen and antibody, serological test results for HIV, anti-HCV antibody and HCV RNA (RT-PCR with a single stranded linear probe; Abbott RealTime kit, Abbott) and HCV genotype (RFMP, GeneMatrix, Yongin, Korea). All measurements of serum activities of AST and ALT were performed by the same method and analysed using a TBA 200FR NEO autoanalyser (Toshiba, Tokyo, Japan). In our institution, the conventional threshold of normal serum ALT has been identified as $40 \mathrm{IU} / \mathrm{L}$ for males and females, as previously described. ${ }^{20}$ BMI $\left(\mathrm{kg} / \mathrm{m}^{2}\right)$ was calculated from the formula weight $/(\text { height })^{2}$, and the patients were categorised as normal $\left(18.5-23 \mathrm{~kg} / \mathrm{m}^{2}\right)$, overweight $\left(23-27.5 \mathrm{~kg} / \mathrm{m}^{2}\right)$ or obese $\left(\geq 27.5 \mathrm{~kg} / \mathrm{m}^{2}\right)$, based on BMI values for Asian populations. ${ }^{21}$ APRI (AST-to-platelet 
Figure 1 Histological findings in patients with chronic hepatitis $\mathrm{C}$ virus infection. The proportion of individuals with severe fibrosis $(A)$ and steatosis $(\mathrm{B})$ are shown according to serum alanine aminotransferase (ALT) level.

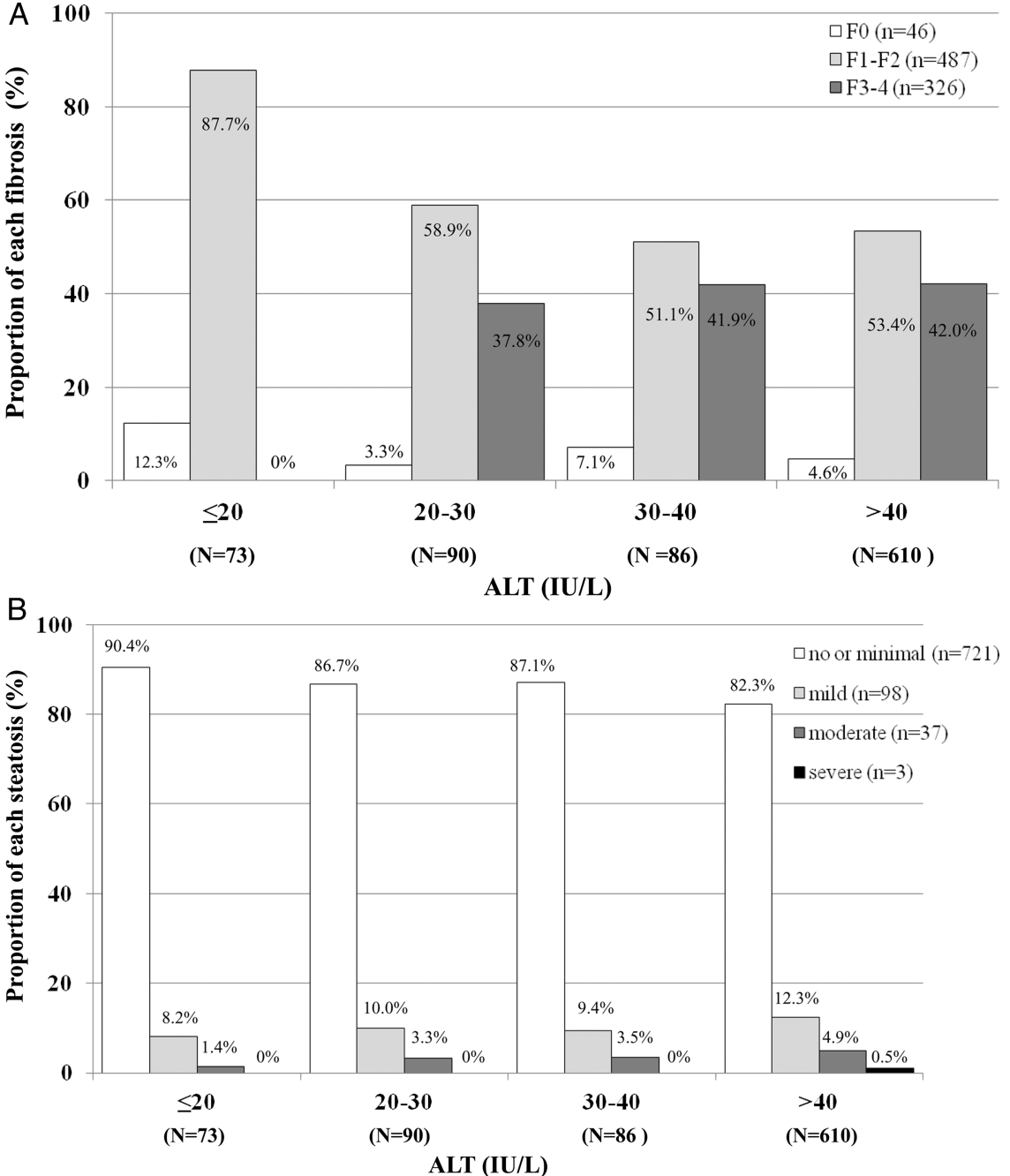

ratio index) and FIB-4 (fibrosis-4) were also calculated as non-invasive fibrosis markers. ${ }^{22} 23$

\section{Preparation and evaluation of liver biopsy specimens}

The clinician's decision for liver biopsy before treatment was usually based on HCV genotype and need for the information on antiviral prognosis. Before the procedure, written informed consent was obtained from all patients. After liver biopsy, patients were carefully monitored every $1 \mathrm{~h}$ for the first $4 \mathrm{~h}$, and thereafter every $6 \mathrm{~h}$ during 1 day. Two or more biopsy specimens, each approximately $1.5 \mathrm{~cm}$ in length, were obtained from every patient. All liver biopsy specimens were fixed in $10 \%$ neutral-buffered formalin. Sections were cut at 3-4 $\mu \mathrm{m}$ thickness and stained with H\&E, Prussian blue and Masson's trichrome stain. All pathological findings were retrospectively obtained by careful review of pathologists' clinical records under the supervision of one senior expert pathologist (EY) who confirmed the final pathological diagnosis. Fibrosis stage and activity grade of the liver specimens were determined based on previously published guidelines. ${ }^{24} 25$ Severe fibrosis was defined as fibrosis stage $\geq 3$ based on the METAVIR scoring system, ${ }^{24}{ }^{25}$ which is also described in the AASLD guidelines. ${ }^{6}$ Fatty changes were categorised as none or minimal $(<5 \%)$, mild $(\geq 5 \%$ and $<30 \%)$, moderate $(\geq 30 \%$ and $<60 \%)$ or severe $(\geq 60 \%){ }^{26}$

\section{Statistical analyses}

The basic clinical characteristics of the patients are expressed as median (range) and frequency. Differences between categorical or continuous variables were analysed using the $\chi^{2}$ test, Fisher's exact test, or Student $t$ test. Multivariate analysis by stepwise linear and logistic regression analysis was performed to assess the predictors of severe hepatic fibrosis in patients. A $p$ value of less than 0.05 (two-tailed) was considered statistically significant in all analyses, which were performed with SPSS V.18.0 (SPSS Inc, Chicago, Illinois, USA).

\section{RESULTS}

\section{Baseline clinical and virological characteristics}

Baseline characteristics of the 859 patients are shown in table 1. The median age of the patient was 52 years (range 19-77 years) and 487 (56.7\%) patients were male. The most common HCV genotypes were 
genotypes 2 and 3, observed in $441(51.3 \%)$ patients, followed by genotype 1 , in $396(46.1 \%)$ patients. Median BMI was $24.2 \mathrm{~kg} / \mathrm{m}^{2}$, and 349 patients $(40.6 \%)$ were overweight or obese. The median serum ALT level was $68 \mathrm{IU} / \mathrm{L}$, and 249 (29\%) patients had normal serum ALT concentrations $(\leq 40 \mathrm{IU} / \mathrm{L})$. Only $1.4 \%$ of the patients had underlying diabetes mellitus (DM). Median scores of APRI and FIB-4 were 0.92 and 2.1, respectively. Severe hepatic fibrosis was not observed in any patient with serum ALT concentration $\leq 20 \mathrm{IU} / \mathrm{L}$ (table 1 ).

\section{Distribution of severe fibrosis and steatosis according to categorised serum ALT levels}

The frequencies of severe fibrosis were $0 \%, 37.8 \%$, $41.9 \%$ and $42 \%$ in patients with serum ALT levels of $\leq 20,20-30,30-40$ and $>40 \mathrm{IU} / \mathrm{L}(\mathrm{p}<0.01)$, respectively (figure 1A), and the frequencies of mild to severe steatosis were $9.6 \%, 13.3 \%, 12.9 \%$ and $17.7 \%$ in the same patient groups, respectively ( $\mathrm{p}=0.07$; figure $1 \mathrm{~B})$.

\section{Clinicobiochemical factors associated with severe hepatic fibrosis}

Severe hepatic fibrosis was observed in 326 (39.7\%) patients. A higher proportion of these patients were older $(\mathrm{p}=0.001)$ and had higher BMI $(\mathrm{p}=0.035)$, AST $(\mathrm{p}=0.001)$ and ALT $(\mathrm{p}<0.001)$, APRI $(<0.001)$ and FIB-4 $(<0.001)$ levels than the individuals without severe hepatic fibrosis. Gender proportion $(p=0.093)$, HCV genotype $(p=0.203)$ and presence of DM $(p=0.068)$ were not significantly different in patients with or without severe hepatic fibrosis (table 2).

\section{Multivariate analysis of factors predicting development of severe hepatic fibrosis}

In the multivariate analysis, categorised age in years (50-60 (OR 4.26, $\mathrm{p}=0.03$ ) and $\geq 60$ (OR 7.53, $\mathrm{p}<0.01$ ) compared with $<30$ ), categorised ALT levels in IU/L (20-30 (OR 16.76, p<0.01), 30-40 (OR 20.02, p<0.01) and $>40($ OR 21.49, $\mathrm{p}<0.01)$ compared with $\leq 20)$ and $\mathrm{BMI}>27.5 \mathrm{~kg} / \mathrm{m}^{2}(\mathrm{OR} 1.65, \mathrm{p}=0.03)$ were independently related to the occurrence of severe hepatic fibrosis in these patients with chronic HCV (table 3). Other individual components of APRI or FIB-4 such as AST level and platelet count were not significantly maintained in multivariate analysis. The number of patients with age $\geq 50$ years, ALT $>20 \mathrm{IU} / \mathrm{L}$ and $\mathrm{BMI}>27.5 \mathrm{~kg} / \mathrm{m}^{2}$ was 71 $(8.3 \%)$ of all 857 included patients. Of these 71 patients, $43(60.6 \%)$ had severe hepatic fibrosis, accounting for $13 \%$ among all of the cases with severe fibrosis.

\section{DISCUSSION}

We have shown that while severe hepatic fibrosis was present in almost $40 \%$ of the patients with chronic HCV with serum ALT levels greater than $20 \mathrm{IU} / \mathrm{L}$, it was absent in all patients with serum ALT levels of $20 \mathrm{IU} / \mathrm{L}$ or below. This finding did not depend on any prebiopsy clinicometabolic parameters identified as associated with
Table 2 Comparison of clinical parameters according to presence of severe fibrosis in patients with $\mathrm{HCV}$

\begin{tabular}{|c|c|c|c|}
\hline \multirow[b]{2}{*}{ Variables } & \multicolumn{2}{|c|}{ Severe fibrosis } & \multirow[b]{2}{*}{ p Value* } \\
\hline & $\begin{array}{l}\text { Absent } \\
(n=533) \\
\text { Group At }\end{array}$ & $\begin{array}{l}\text { Present } \\
(n=326) \\
\text { Group Bł }\end{array}$ & \\
\hline \multicolumn{3}{|l|}{ Age (years), n (\%) } & 0.001 \\
\hline$<30$ & $25(4.7)$ & $3(0.9)$ & \\
\hline$\geq 30$ and $<40$ & 89 (16.7) & $22(6.7)$ & \\
\hline$\geq 40$ and $<50$ & $155(29.1)$ & $68(20.9)$ & \\
\hline$\geq 50$ and $<60$ & $160(30.0)$ & 103 (31.6) & \\
\hline$\geq 60$ & $104(19.5)$ & $130(39.9)$ & \\
\hline Male gender, n (\%) & $312(58.5)$ & $175(53.7)$ & 0.093 \\
\hline \multicolumn{3}{|l|}{ BMI $\left(\mathrm{kg} / \mathrm{m}^{2}\right), \mathrm{n}(\%)$} & 0.035 \\
\hline$<23$ & $198(37.3)$ & $105(32.0)$ & \\
\hline$\geq 23$ and $<27.5$ & $264(49.7)$ & $160(48.8)$ & \\
\hline$\geq 27.5$ & $69(13.0)$ & $63(19.2)$ & \\
\hline \multicolumn{3}{|l|}{ HCV genotype } & 0.203 \\
\hline 1 & $233(43.7)$ & $163(50.0)$ & \\
\hline 2 or 3 & $286(53.7)$ & $155(47.5)$ & \\
\hline others & $14(2.6)$ & $8(2.5)$ & \\
\hline \multicolumn{3}{|l|}{ AST (IU/L), n (\%) } & 0.001 \\
\hline$\leq 20$ & $41(7.7)$ & $2(0.6)$ & \\
\hline$>20$ and $\leq 30$ & $93(17.4)$ & $19(5.8)$ & \\
\hline$>30$ and $\leq 40$ & $86(16.1)$ & $26(8.0)$ & \\
\hline$>40$ & $313(58.7)$ & $279(85.6)$ & \\
\hline \multicolumn{3}{|l|}{ ALT (IU/L), n (\%) } & $<0.001$ \\
\hline$\leq 20$ & $73(13.7)$ & $0(0)$ & \\
\hline$>20$ and $\leq 30$ & 56 (10.5) & $34(10.4)$ & \\
\hline$>30$ and $\leq 40$ & $50(9.4)$ & $36(11.0)$ & \\
\hline$>40$ & $354(66.4)$ & $256(78.5)$ & \\
\hline $\begin{array}{l}\text { Platelet count } \\
\left(\times 10^{3} / \mathrm{mm}^{3}\right) \S\end{array}$ & $133.3 \pm 52.7$ & $190.3 \pm 55.2$ & $<0.001$ \\
\hline APRI§ & $1.03 \pm 1.34$ & $2.24 \pm 3.41$ & $<0.001$ \\
\hline FIB-4§ & $2.13 \pm 1.79$ & $5.49 \pm 6.56$ & $<0.001$ \\
\hline DM, n (\%) & $4(0.8)$ & $8(2.5)$ & 0.068 \\
\hline $\begin{array}{l}\text { Cholesterol } \\
\text { (mg/dL)§ }\end{array}$ & $155.7 \pm 33.1$ & $157.1 \pm 30.8$ & 0.525 \\
\hline \multicolumn{4}{|c|}{$\begin{array}{l}\text { *pvalue for difference between groups A and B. } \\
\text { †Patients with fibrosis stage } 0-2 \text {. } \\
\text { †Patients with fibrosis stage } 3-4 \text {. } \\
\text { §Mean }( \pm \text { SD). } \\
\text { ALT, alanine aminotransferase; APRI, aspartate } \\
\text { aminotransferase-to-platelet ratio index; AST, aspartate } \\
\text { aminotransferase; BMI, body mass index; DM, diabetes mellitus; } \\
\text { FIB-4, fibrosis-4; HCV, hepatitis C virus. }\end{array}$} \\
\hline
\end{tabular}

serum ALT activity in previous studies. ${ }^{27} 28$ It was also notable that older age ( $\geq 50$ years) and obesity, as well as higher than normal levels of serum ALT $(>20 \mathrm{IU} / \mathrm{L})$, were closely associated with severe hepatic fibrosis in these patients. In particular, severe hepatic fibrosis was observed in about $60 \%$ of patients aged $\geq 50$ years with serum ALT concentrations $>20 \mathrm{IU} / \mathrm{L}$ and BMI $>27.5 \mathrm{~kg} / \mathrm{m}^{2}$, and these patients accounted for $13 \%$ among all of the cases with severe fibrosis.

Consensus has already been reached about the necessity for initiating anti-HCV treatment in patients with chronic HCV with moderate hepatitis or severe fibrosis, especially in young patients with a long expected life 
Table 3 Multivariate analysis of factors predicting severe fibrosis in patients with HCV

\begin{tabular}{|c|c|c|c|c|c|c|}
\hline \multirow[b]{2}{*}{ Variables } & \multicolumn{3}{|c|}{ Univariate analysis } & \multicolumn{3}{|c|}{ Multivariate analysis* } \\
\hline & $\overline{\text { OR }}$ & $95 \% \mathrm{CI}$ & p Value & $\overline{\text { OR }}$ & $95 \% \mathrm{Cl}$ & p Value \\
\hline \multicolumn{7}{|l|}{ Age (years) } \\
\hline$<30$ (control) & - & - & - & - & - & - \\
\hline$\geq 30$ and $<40$ & 2.06 & 0.57 to 7.45 & 0.27 & 1.86 & 0.49 to 7.07 & 0.36 \\
\hline$\geq 40$ and $<50$ & 3.66 & 1.07 to 12.52 & 0.04 & 2.87 & 0.79 to 10.37 & 0.11 \\
\hline$\geq 50$ and $<60$ & 5.37 & 1.58 to 18.22 & 0.01 & 4.26 & 1.19 to 15.32 & 0.03 \\
\hline$\geq 60$ & 10.42 & 3.06 to 34.46 & $<0.01$ & 7.53 & 2.09 to 27.11 & $<0.01$ \\
\hline Male gender & 1.22 & 0.92 to 1.61 & 0.16 & - & - & - \\
\hline \multicolumn{7}{|l|}{ AST (IU/L) } \\
\hline$\leq 20$ (control) & - & - & - & - & - & - \\
\hline$>20$ and $\leq 30$ & 4.19 & 0.93 to 18.82 & 0.06 & 0.95 & 0.22 to 4.41 & 0.95 \\
\hline$>30$ and $\leq 40$ & 6.19 & 1.40 to 27.38 & 0.02 & 0.97 & 0.22 to 4.22 & 0.97 \\
\hline$>40$ & 18.27 & 4.38 to 76.24 & $<0.01$ & 3.36 & 0.78 to 14.34 & 0.10 \\
\hline \multicolumn{7}{|l|}{ ALT (IU/L) } \\
\hline$\leq 20$ (control) & - & - & - & - & - & - \\
\hline$>20$ and $\leq 30$ & 19.55 & 4.96 to 93.59 & $<0.01$ & 16.76 & 3.39 to 82.66 & $<0.01$ \\
\hline$>30$ and $\leq 40$ & 20.56 & 5.88 to 111.07 & $<0.01$ & 20.02 & 4.01 to 84.73 & $<0.01$ \\
\hline$>40$ & 25.67 & 6.24 to 105.62 & $<0.01$ & 21.49 & 4.34 to 85.43 & $<0.01$ \\
\hline \multicolumn{7}{|l|}{ BMI $\left(\mathrm{kg} / \mathrm{m}^{2}\right)$} \\
\hline$<23$ (control) & - & - & - & - & - & - \\
\hline$\geq 23$ and $<27.5$ & 1.14 & 0.84 to 1.55 & 0.39 & 0.99 & 0.71 to 1.39 & 0.97 \\
\hline$\geq 27.5$ & 1.72 & 1.14 to 2.61 & 0.01 & 1.65 & 1.05 to 2.61 & 0.03 \\
\hline $\mathrm{DM}$ & 2.67 & 0.39 to 18.17 & 0.32 & - & - & - \\
\hline Cholesterol (mg/dL) & 0.99 & 0.99 to 1.01 & 0.38 & - & - & - \\
\hline
\end{tabular}

span ahead. ${ }^{6}$ However, the necessity for routine liver biopsy to evaluate fibrosis stage before anti-HCV treatment remains controversial. Aside from the fact that anti-HCV treatment has potential adverse effects, it is not effective for all patients, and is relatively expensive, ${ }^{29}$ the biopsy procedure itself is associated with adverse effects such as pain, bleeding and bowel perforation, ${ }^{8}$ which may incur additional medical care costs and cause patients distress and anxiety. ${ }^{30}$ In our series, about onefourth of the biopsied patients experienced mild or moderate abdominal pain after liver biopsy, although there were no serious complications requiring a long hospital stay. Indeed, some patients may hesitate to receive anti-HCV treatment based on histological evidence, even despite only the minor chance of serious adverse events occurring owing to biopsy. Thus, simple clinicobiochemical factors capable of predicting severe hepatic fibrosis without pathological evidence could be practically helpful in deciding on the treatment for patients with chronic HCV.

Although previous studies have evaluated factors associated with histological findings of patients with chronic HCV in Western populations, ${ }^{18}{ }^{31-34}$ there is still a lack of data about whether the findings can be confidently extrapolated to Asian patients. Interestingly, our Asian data show that severe hepatic fibrosis was not present in patients with low normal serum ALT levels $(\leq 20 \mathrm{IU} / \mathrm{L})$, supporting a wait-and-see approach for these patients, particularly those with clinical or genetic parameters related to suboptimal antiviral treatment response. ${ }^{6}$ In contrast, more advanced age ( $\geq 50$ years), obesity and serum ALT levels $>20 \mathrm{IU} / \mathrm{L}$ were independent predictors of significant hepatic fibrosis. These findings suggest that immediate anti-HCV treatment without performing a liver biopsy may be beneficial for patients above 50 years (albeit not for elderly patients ( $>65$ years), weighing the potential risks and benefits ${ }^{35}$ ), especially for obese genotype 2 or 3 patients with serum ALT concentrations $>20 \mathrm{IU} / \mathrm{L}$, because more than $80 \%$ of patients with HCV with genotype 2 or 3 achieve an SVR to standard-of-care treatment. ${ }^{12}$ Given the better antiviral response of Asian patients, who have the favourable IL28B genotype more frequently than Western individuals, ${ }^{36}$ it may be preferable to initiate antiviral treatment for young Asian patients infected with genotype 1 HCV without pathology results if serum ALT levels are above $20 \mathrm{IU} / \mathrm{L}$. Moreover, our results suggest that even in patients with genotype $1 \mathrm{HCV}$ infection, which is a well-known predictor of negative antiviral treatment response, ${ }^{6}$ high-risk factors for significant hepatic fibrosis such as serum ALT levels of $>20 \mathrm{IU} / \mathrm{L}$, age $\geq 50$ years and obesity may be deemed to justify an active antiviral approach, preferably with triple regimens, without liver biopsy findings.

We observed severe hepatic fibrosis in about $40 \%$ of the patients with normal ALT levels (ie, less than $40 \mathrm{IU} / \mathrm{L}$ ). 
This rate was similar to that in patients with elevated ALT levels. This suggests that the decision to initiate anti-HCV treatment should not be based simply on serum ALT levels, especially in patients with serum ALT concentrations $>20 \mathrm{IU} / \mathrm{L}$. Likewise, patients with serum ALT of 20$40 \mathrm{IU} / \mathrm{L}$ should not be excluded from antiviral therapy simply because of normal ALT levels. Moreover, liver biopsy may be required for decision-making regarding antiviral treatment when serum ALT levels are 20-40 IU/L in older ( $>50$ years) and obese patients who are reluctant to receive treatment.

It has been reported that host factors such as age and obesity are associated with the development of hepatic fibrosis, ${ }^{5} 37$ and in this respect the outcomes of our study are similar to those of previous studies. ${ }^{5} 37$ Although non-invasive tests such as elastography, nonalcoholic fatty liver disease fibrosis score, and APRI or the FIB-4 score have been developed to estimate hepatic fibrosis, their accuracy has not been sufficiently validated. $^{22} 2338{ }^{39}$ Moreover, these tests involve high cost and additional calculations. However, we have identified inexpensive and simple clinical parameters that are not expensive to measure and that can aid decision-making about severe hepatic fibrosis.

Despite the extensive analyses using large scale pathology-based data sets, a major limitation of the current study is that the data are from a single institution and a single ethnic type. Because of the differences in procedures for serum ALT measurement in different clinical laboratories and the fact that Asian BMI cut-off points differ from those of Western populations, ${ }^{21} 40$ further multicentre and multiethnic studies are required for external validation and wider use of our estimates. In addition, our cohort did not include patients with $\mathrm{HCV}$-infection who received antiviral treatment without resorting to biopsy or who were never treated, which may introduce a selection bias. Finally, observational variations among pathologists in histological evaluation should be taken into account when interpreting the present results and further applying them in clinical practice.

In conclusion, advanced age ( $\geq 50$ years), obesity and serum ALT levels $>20 \mathrm{IU} / \mathrm{L}$ are closely associated with the development of severe hepatic fibrosis in Korean patients with chronic HCV infection. These findings could facilitate clinical decision-making in the management of patients with HCV-infection.

\section{Acknowledgements This study was supported by an Inha University Research Grant.}

Contributors Y-JJ and JHS were responsible for the concept and design of the study, the acquisition, analysis and interpretation of the data, and drafting of the manuscript. GAK, EY, KMK, Y-SL and HCL helped with the acquisition, analysis, interpretation of the data and critical revision of the manuscript for important intellectual content.

Funding This research received no specific grant from any funding agency in the public, commercial or not-for-profit sectors.

Competing interests None.
Provenance and peer review Not commissioned; externally peer reviewed.

Data sharing statement No additional data are available.

Open Access This is an Open Access article distributed in accordance with the Creative Commons Attribution Non Commercial (CC BY-NC 4.0) license, which permits others to distribute, remix, adapt, build upon this work noncommercially, and license their derivative works on different terms, provided the original work is properly cited and the use is non-commercial. See: http:// creativecommons.org/licenses/by-nc/4.0/

\section{REFERENCES}

1. Alter MJ. Epidemiology of hepatitis C. Hepatology 1997;26:62S-5S.

2. Lauer GM, Walker BD. Hepatitis C virus infection. N Engl J Med 2001;345:41-52.

3. Alter MJ, Kruszon-Moran D, Nainan OV, et al. The prevalence of hepatitis C virus infection in the United States, 1988 through 1994. N Engl J Med 1999;341:556-62.

4. Liang TJ, Rehermann B, Seeff LB, et al. Pathogenesis, natura history, treatment, and prevention of hepatitis C. Ann Intern Med 2000;132:296-305.

5. Poynard T, Bedossa P, Opolon P. Natural history of liver fibrosis progression in patients with chronic hepatitis $\mathrm{C}$. The OBSVIRC METAVIR, CLINIVIR, and DOSVIRC groups. Lancet 1997;349:825-32.

6. Ghany MG, Strader DB, Thomas DL, et al. Diagnosis, management, and treatment of hepatitis C: an update. Hepatology 2009;49:1335-74

7. Bravo AA, Sheth SG, Chopra S. Liver biopsy. N Engl J Med 2001;344:495-500.

8. Dienstag JL. The role of liver biopsy in chronic hepatitis C. Hepatology 2002;36:S152-60.

9. Everhart JE, Stolar M, Hoofnagle JH. Management of hepatitis C: a national survey of gastroenterologists and hepatologists. Hepatology 1997;26:78S-82S.

10. Manns MP, McHutchison JG, Gordon SC, et al. Peginterferon alfa-2b plus ribavirin compared with interferon alfa-2b plus ribavirin for initial treatment of chronic hepatitis C: a randomised trial. Lancet 2001;358:958-65.

11. Fried MW, Shiffman ML, Reddy KR, et al. Peginterferon alfa-2a plus ribavirin for chronic hepatitis $\mathrm{C}$ virus infection. $N$ Engl $\mathrm{J}$ Med 2002;347:975-82.

12. Shiffman ML, Suter F, Bacon BR, et al. Peginterferon alfa-2a and ribavirin for 16 or 24 weeks in HCV genotype 2 or 3. N Engl J Med 2007;357:124-34

13. Poordad F, McCone J Jr, Bacon BR, et al. Boceprevir for untreated chronic HCV genotype 1 infection. N Engl J Med 2011;364:1195-206.

14. Jacobson IM, McHutchison JG, Dusheiko G, et al. Telaprevir for previously untreated chronic hepatitis $C$ virus infection. $N$ Engl J Med 2011;364:2405-16.

15. Sherman KE, Flamm SL, Afdhal NH, et al. Response-guided telaprevir combination treatment for hepatitis $\mathrm{C}$ virus infection N Engl J Med 2011;365:1014-24.

16. European Association for Study of Liver. EASL Clinical Practice Guidelines: management of hepatitis $\mathrm{C}$ virus infection. $J$ Hepatol 2014;60:392-420.

17. Ghany MG, Nelson DR, Strader DB, et al. An update on treatment of genotype 1 chronic hepatitis $C$ virus infection: 2011 practice guideline by the American Association for the Study of Liver Diseases. Hepatology 2011;54:1433-44.

18. Pradat $\mathrm{P}$, Alberti A, Poynard T, et al. Predictive value of ALT levels for histologic findings in chronic hepatitis $\mathrm{C}$ : a European collaborative study. Hepatology 2002;36:973-7.

19. Ichino N, Osakabe K, Nishikawa T, et al. A new index for non-invasive assessment of liver fibrosis. World J Gastroenterol 2010;16:4809-16.

20. Lee JK, Shim JH, Lee HC, et al. Estimation of the healthy upper limits for serum alanine aminotransferase in Asian populations with normal liver histology. Hepatology 2010;51:1577-83.

21. WHO Expert Consultation. Appropriate body-mass index for Asian populations and its implications for policy and intervention strategies. Lancet 2004;363:157-63.

22. Vallet-Pichard A, Mallet V, Nalpas B, et al. FIB-4: an inexpensive and accurate marker of fibrosis in $\mathrm{HCV}$ infection. Comparison with liver biopsy and fibrotest. Hepatology 2007;46:32-6.

23. Lackner C, Struber G, Liegl B, et al. Comparison and validation of simple noninvasive tests for prediction of fibrosis in chronic hepatitis C. Hepatology 2005;41:1376-82. 
24. [No authors listed]. Intraobserver and interobserver variations in liver biopsy interpretation in patients with chronic hepatitis $\mathrm{C}$. The French METAVIR Cooperative Study Group. Hepatology 1994;20:15-20.

25. Bedossa $P$, Poynard T. An algorithm for the grading of activity in chronic hepatitis C. The METAVIR Cooperative Study Group. Hepatology 1996;24:289-93.

26. Lee JY, Kim KM, Lee SG, et al. Prevalence and risk factors of non-alcoholic fatty liver disease in potential living liver donors in Korea: a review of 589 consecutive liver biopsies in a single center. $J$ Hepatol 2007;47:239-44.

27. Prati $D$, Shiffman ML, Diago M, et al. Viral and metabolic factors influencing alanine aminotransferase activity in patients with chronic hepatitis C. J Hepatol 2006;44:679-85.

28. Kobayashi $\mathrm{Y}$, Kawaguchi $\mathrm{Y}$, Mizuta T, et al. Metabolic factors are associated with serum alanine aminotransferase levels in patients with chronic hepatitis C. J Gastroenterol 2011;46:529-35.

29. Levine RA. Treating histologically mild chronic hepatitis C: monotherapy, combination therapy, or tincture of time? Ann Intern Med 1998;129:323-6.

30. Regev A, Berho M, Jeffers LJ, et al. Sampling error and intraobserver variation in liver biopsy in patients with chronic HCV infection. Am J Gastroenterol 2002;97:2614-18.

31. Alberti A, Morsica G, Chemello L, et al. Hepatitis C viraemia and liver disease in symptom-free individuals with anti-HCV. Lancet 1992;340:697-8.

32. Gholson CF, Morgan K, Catinis G, et al. Chronic hepatitis C with normal aminotransferase levels: a clinical histologic study. $A m \mathrm{~J}$ Gastroenterol 1997;92:1788-92.
33. Jamal MM, Soni A, Quinn PG, et al. Clinical features of hepatitis C-infected patients with persistently normal alanine transaminase levels in the Southwestern United States. Hepatology 1999:30:1307-11.

34. Wai CT, Greenson JK, Fontana RJ, et al. A simple noninvasive index can predict both significant fibrosis and cirrhosis in patients with chronic hepatitis C. Hepatology 2003;38:518-26.

35. Puoti C, Bellis L, Guarisco R, et al. HCV carriers with normal alanine aminotransferase levels: healthy persons or severely ill patients? Dealing with an everyday clinical problem. Eur J Intern Med 2010;21:57-61.

36. Tanaka $\mathrm{Y}$, Nishida N, Sugiyama M, et al. Genome-wide association of IL28B with response to pegylated interferon-alpha and ribavirin therapy for chronic hepatitis C. Nat Genet 2009;41: 1105-9.

37. Ratziu V, Giral P, Charlotte F, et al. Liver fibrosis in overweight patients. Gastroenterology 2000;118:1117-23.

38. Huwart L, Sempoux C, Salameh N, et al. Liver fibrosis: noninvasive assessment with MR elastography versus aspartate aminotransferase-to-platelet ratio index. Radiology 2007;245:458-66.

39. McPherson S, Stewart SF, Henderson E, et al. Simple non-invasive fibrosis scoring systems can reliably exclude advanced fibrosis in patients with non-alcoholic fatty liver disease. Gut 2010;59: 1265-9.

40. Dutta A, Saha C, Johnson CS, et al. Variability in the upper limit of normal for serum alanine aminotransferase levels: a statewide study. Hepatology 2009;50:1957-62. 